\title{
Wpływ zmiany wytycznych ASCO-CAP na ocenę statusu genu HER2 metodą FISH w kwalifikacji do terapii anty-HER2 w raku piersi
}

\author{
Urszula Piekarska ${ }^{1}$, Agnieszka Chudy ${ }^{1}$, Aneta Wojnowska ${ }^{1}$, Katarzyna Olszewska ${ }^{1}$, \\ Magdalena Grabowska-Kierył' , Joanna Owczarek², Wojciech Olszewski², \\ Michał Ł. Szafron¹, Barbara Pieńkowska-Grela ${ }^{1}$
}

\begin{abstract}
Wstęp. Rak piersi jest najczęstszym nowotworem u kobiet w Polsce. Nadmierna ekspresja białka HER2 lub amplifikacja genu HER2 jest związana ze złym rokowaniem i stanowi wskazanie do zastosowania terapii anty-HER2. W przypadkach wątpliwych rozstrzygającym badaniem jest ocena FISH, wskazująca status amplifikacji genu HER2 według obowiązujących wytycznych ASCO-CAP, które w roku 2013 uległy zmianom. Celem pracy było sprawdzenie, czy i w jaki sposób zmiana zaleceń wpłynęła na rozkład wyników badań FISH w tej grupie pacjentów.

Materiały i metody. Analizie porównawczej poddano wyniki rutynowej diagnostyki metodą FISH w dwóch niezależnych grupach pacjentów z zastosowaniem dwóch różnych kryteriów oceny (ASCO-CAP 2007 dla $n=680$ i ASCO-CAP 2013 dla $n=851$ ) oraz w grupie 763 pacjentów, gdzie zastosowano równolegle obydwa kryteria oceny.

Wyniki. Porównanie wyników uzyskanych $w$ dwóch niezależnych grupach wykazało brak istotnej zmiany odsetka wyników HER2-dodatnich (z amplifikacją) po zmianie kryteriów oceny. Istotne statystycznie okazało się zmniejszenie grupy wyników HER2-negatywnych (bez amplifikacji) z 76,2\% na 61,8\% przy rozszerzeniu grupy niejednoznacznej (o nieokreślonym statusie amplifikacji) z 0,4\% do 13,6\%. Grupa badana równolegle wg kryteriów 2007 i 2013 wykazała różnice istotne statystycznie. Zanotowano wzrost przypadków HER2-pozytywnych z 10,6\% do 16,8\%, znaczny wzrost wyników niejednoznacznych, z 4,2\% na 15,6\%, przy równoczesnym spadku wyników negatywnych z $85,2 \%$ na $67,6 \%$. Wnioski. Zastosowanie nowych wytycznych ASCO-CAP 2013 w ocenie statusu genu HER2 wpływa na zawężenie grupy wyników negatywnych, natomiast rozszerza grupę wyników pozytywnych i niejednoznacznych. Wynik taki wskazuje na rozszerzenie dostępu do kwalifikacji w kierunku terapii anty-HER2. Natomiast istotny wzrost odsetka pacjentów z wynikiem o nieokreślonym statusie amplifikacji genu HER2 wskazuje na konieczność pogłębionej w tej grupie oceny FISH w celu uzyskania możliwości jednoznacznej stratyfikacji do grup ryzyka.
\end{abstract}

\section{The impact of changes in ASCO-CAP recommendations on the FISH-based assessment} of the HER2 gene status in the qualification of breast cancer patients for HER2-targeted therapy Introduction. Breast cancer is the most common cancer among Polish women. Overexpression of the HER2 protein or HER2 gene amplification is associated with a poor prognosis, simultaneously being an indication for the HER2-targeted therapy. In equivocal cases, the FISH assay is used for the final identification of the HER2 gene status. This evaluation should be performed according to the ASCO-CAP guidelines which have been changed in 2013. The aim of this study was to assess whether and how the changes of recommendations affected the distribution of the FISH results. Materials and methods. The results of routine diagnostic FISH analyses were compared for two independent groups of patients assessed with different evaluation criteria (ASCO-CAP 2007 for $n=680$ and ASCO-CAP $2013 n=851$ ), and also in a group of 763 patients, where both criteria were used simultaneously.

\footnotetext{
${ }^{1}$ Pracownia Genetyki Nowotworów

${ }^{2}$ Pracownia Patologii Narządowej Nowotworów

Zakład Patologii i Diagnostyki Laboratoryjnej

Centrum Onkologii — Instytut im. Marii Skłodowskiej-Curie w Warszawie
} 
Results. A comparison of the results obtained in two independent groups showed that the change of evaluation criteria did not alter the percentage of HER2-positive tests (with HER2 amplification). However, the frequency of HER2-negative analyses (without HER2 amplification) diminished significantly from $76.2 \%$ to $61.8 \%$, whereas the equivocal group (with an indefinite status of HER2 amplification) increased from $0.4 \%$ to $13.6 \%$. In the group where both criteria from 2007 and 2013 were used, we also discovered statistically significant differences. The frequency of HER2-positive results were elevated from $10.6 \%$ to $16.8 \%$. The equivocal results were also found more often, rising from $4.2 \%$ to $15.6 \%$, while the number of negative results lowered from $85.2 \%$ to $67.6 \%$.

Conclusions. The use of ASCO/CAP recommendations for the assessment of the HER2 gene status reduces the group of negative results, and concurrently enlarges the number of positive and equivocal ones. This indicates that the new criteria extends the access to HER2-targeted therapy. Nevertheless, they also raise the frequency of analyses with an indefinite status of the HER2 gene. Our outcome suggests that there is a need for an enhanced FISH-based evaluation of this gene in the last group of patients in order to provide them with an unambiguous stratification to risk groups.

NOWOTWORY J Oncol 2016; 66, 2: 109-117

Słowa kluczowe: rak piersi, HER2, rekomendacje ASCO-CAP

Key words: breast cancer, HER2, ASCO-CAP guidelines

\section{Wstęp}

Rak piersi jest najczęstszym nowotworem złośliwym u kobiet w Polsce [1]. Według Krajowego Rejestru Nowotworów w 2012 roku zdiagnozowano w Polsce 17000 nowych przypadków zachorowania i 5574 zgonów spowodowanych tą chorobą (13,3\% zgonów z powodu nowotworów złośliwych u kobiet). Zachorowalność na ten nowotwór u mężczyzn jest znacznie niższa, w roku 2012 odnotowano 144 nowych zachorowań [2]. Zaburzenia genu HER2 (human epidermal growth factor receptor, częściej stosowane synonimy: ERBB2, HER-2/neu) stwierdza się w różnych nowotworach nabłonkowych, najczęściej jednak występują one u pacjentów z rakiem piersi i rakiem jajnika [3].

Gen HER2 jest protoonkogenem zlokalizowanym na długim ramieniu chromosomu 17, w prążku q12, kodującym białkowy receptor dla czynnika wzrostu [4]. Prawidłowe komórki somatyczne zawierają dwie kopie genu HER2 i mają na swojej powierzchni niewielkie ilości białka HER2, z niewielkim zakresem zmienności pomiędzy różnymi tkankami. Te powierzchniowe glikoproteiny są zaangażowane w przekazywanie sygnałów związanych z kontrolą wzrostu i funkcjonowania komórek [5]. Nadekspresja receptora HER2 występuje u 10\%-20\% chorych na raka piersi [6]. Podstawowym mechanizmem nadekspresji genu HER2 jest jego amplifikacja, powodująca stymulację mitogenną zmienionych komórek [7, 8]. W raku piersi wzmożona ekspresja białka HER2 stanowi istotny czynnik rokowniczy i predykcyjny. Jej obecność powoduje większą agresywność choroby, krótszy czas całkowitego przeżycia oraz skrócenie czasu do nawrotu choroby, tak więc jest związana ze złym rokowaniem [9].

Wykazanie zależności pomiędzy statusem ekspresji białka HER2 a rokowaniem oraz dostępność leczenia adiuwantowego anty-HER2 (trastuzumab, herceptyna - zhumanizowane przeciwciało monoklonalne) sprawiły, że określenie statusu genu HER2 stało się integralnym etapem procesu diagnostycznego w raku piersi [10]. Nadmierna ekspresja białka HER2 lub amplifikacja genu HER2 stanowią wskazanie do zastosowania terapii adiuwantowej. Skuteczne leczenie anty-HER2 jest możliwe w przypadkach raka piersi z potwierdzoną nadekspresją białka i/lub amplifikacją genu HER2, dlatego ważne jest wyselekcjonowanie pacjentów potencjalnie wrażliwych.

Rutynowo badanie statusu HER2 w tkance guza jest procesem dwustopniowym. W pierwszym etapie wykonuje się ocenę ekspresji białka HER2 w badaniu immunohistochemicznym (IHC). Technika ta polega na przyłączaniu przeciwciał przeciwko badanemu białku oraz na ocenie stopnia wybarwienia błon cytoplazmatycznych w komórkach raka. Stopień i ciągłość wybarwienia klasyfikuje się w czterostopniowej skali: 0, 1, 2, 3. Uzyskanie wartości 0-1 świadczy o braku nadekspresji, wartość 3+ wskazuje jednoznacznie na obecność nadekspresji. Ocena 2+ stanowi wartość pośrednią - taki wynik uznawany jest za niejednoznaczny i wymaga precyzyjnego określenia statusu genu metodą fluorescencyjnej hybrydyzacji in situ (FISH). Sytuację taką obserwuje się w 15\%-24\% badanych prób [9,11].

Technika FISH pozwala na bezpośrednią ocenę liczby kopii genu HER2 w komórkach nowotworu. Metoda jest bardziej czuła i swoista w porównaniu z IHC [12]. Badanie wykonywane jest na skrawkach tkankowych uzyskanych z bloczków parafinowych, ocenionych uprzednio przez lekarza patomorfologa. Detekcji genu dokonuje się za pomocą sond DNA. Sondy są to znakowane fluorescencyjnie fragmenty oligonukleotydów, komplementarne do ocenianego regionu DNA. Dla oznaczenia statusu genu HER2 używa się komplementarnej do niego sondy. Zliczenie fluorescencyjnych sygnałów sondy znakującej HER2 w poszczególnych jądrach interfazowych pozwala na bezpośrednią ocenę licz- 


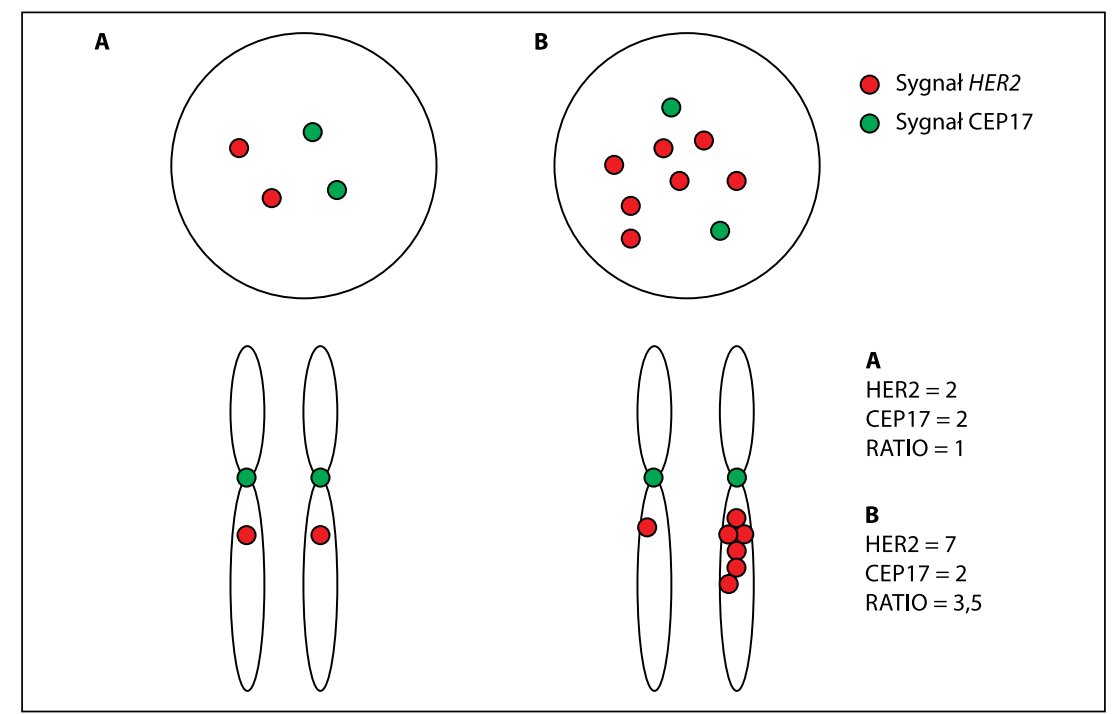

Rycina 1. Sonda podwójna - obraz widziany w mikroskopie fluorescencyjnym (górna cześć schematu) oraz schematyczne przedstawienie pochodzenia wzoru znakowania przy zastosowaniu sondy podwójnej. A — brak amplifikacji, wynik negatywny; B — obecna amplifikacja, wynik pozytywny

by kopii badanego genu na komórkę. Dla lepszej kontroli stosuję się sondę podwójną (dual-color, dual-probe). Obok sondy HER2 zawiera ona równolegle drugą sondę, znakującą odmiennym fluorochromem chromatynę okołocentromerową chromosomu 17 (CEP17 chromosome enumeration probe 17) (ryc. 1).

Status genu HER2 (amplifikacja vs brak amplifikacji) określa się, oceniając liczbę sygnałów pochodzących z sondy w każdej z analizowanych komórek, następnie wylicza się średnią ilość sygnałów na komórkę w obrębie badanej próbki.W systemie sondy podwójnej zlicza się liczby sygnałów pochodzących z sondy znakującej obszar genu HER2 (sygnał czerwony) i centromeru 17 (sygnał zielony) (ryc. 1). RATIO, które oznacza stosunek średniej liczby sygnałów pochodzących od genu HER2 do średniej liczny sygnałów obszaru CEP17 (HER2: CEP17), wyznacza się na podstawie analizy minimum 20 dobrze wyznakowanych jąder interfazowych w reprezentatywnym obszarze preparatu. Przed zliczaniem sygnałów należy przejrzeć cały preparat w celu sprawdzenia, czy nie występuje zauważalna heterogenność tkanki, ujawniająca się zróżnicowaną ilością sygnałów. Zalecenia dobrej praktyki laboratoryjnej wymagają, aby mikroskopowa ocena FISH została powtórzona niezależnie przez drugiego obserwatora [13].

Interpretacja uzyskanego wyniku powinna odbywać się zgodnie z aktualnie obowiązującymi zaleceniami ekspertów. Obecnie obowiązują kryteria ASCO-CAP 2013, stworzone przez Amerykańskie Stowarzyszenie Onkologów Klinicznych oraz Amerykańskie Towarzystwo Patologów (American Society of Clinical Oncology/College of American Pathologists) $[14,15]$.
Wytyczne dotyczące interpretacji wyników FISH stopniowo ulegają zmianom. Zgoda FDA (Food and Drug Administration) na użycie techniki FISH w ocenie statusu genu HER2 nastąpiła w 2002 roku. Pierwsze wytyczne zakładały, że przy zastosowaniu sondy pojedynczej na wynik pozytywny, tj. amplifikację genu HER2, wskazuje średnia liczba sygnałów sondy HER2 powyżej 4,0 na komórkę. W przypadku zastosowania sondy podwójnej wynik pozytywny stwierdzano, gdy stosunek (RATIO) liczby kopii HER2 do CEP17 był większy lub równy 2,0 [16-19].

W 2007 roku ASCO-CAP wydało oficjalne rekomendacje dotyczące oceny receptora HER2 w raku piersi, gdzie uszczegółowiono zasady interpretacji wyników [20]. W przypadku zastosowania sondy pojedynczej wynik pozytywny wskazywała średnia wartość powyżej 6,0 sygnałów na komórkę, wynik negatywny - poniżej 4,0 na komórkę. W analizie z zastosowaniem sondy podwójnej za wynik pozytywny uznawano przypadki, w których RATIO przekraczało 2,2, natomiast wartości RATIO mniejsze niż 1,8 wskazywały wynik negatywny. Nowością było wprowadzenie grupy granicznej, o niezdefiniowanym statusie genu HER2, do której zaliczono przypadki z wartością RATIO w przedziale 1,8-2,2 lub liczbą sygnałów HER2 4,0-6,0 dla sondy pojedynczej. W tak określonej grupie granicznej mieściły się przypadki o heterogennym znakowaniu oraz takie, gdzie trudność z określeniem statusu HER2 wynikała z podwyższonej liczby sygnałów CEP17.

Nieprawidłowości w ilości sygnałów CEP17 mogą być spowodowane polisomią chromosomu 17 bądź wybiórczym powieleniem okolicy centromerowej chromosomu 17 (ryc. 2). Tego rozróżnienia nie da się jednak wykazać w badaniu 


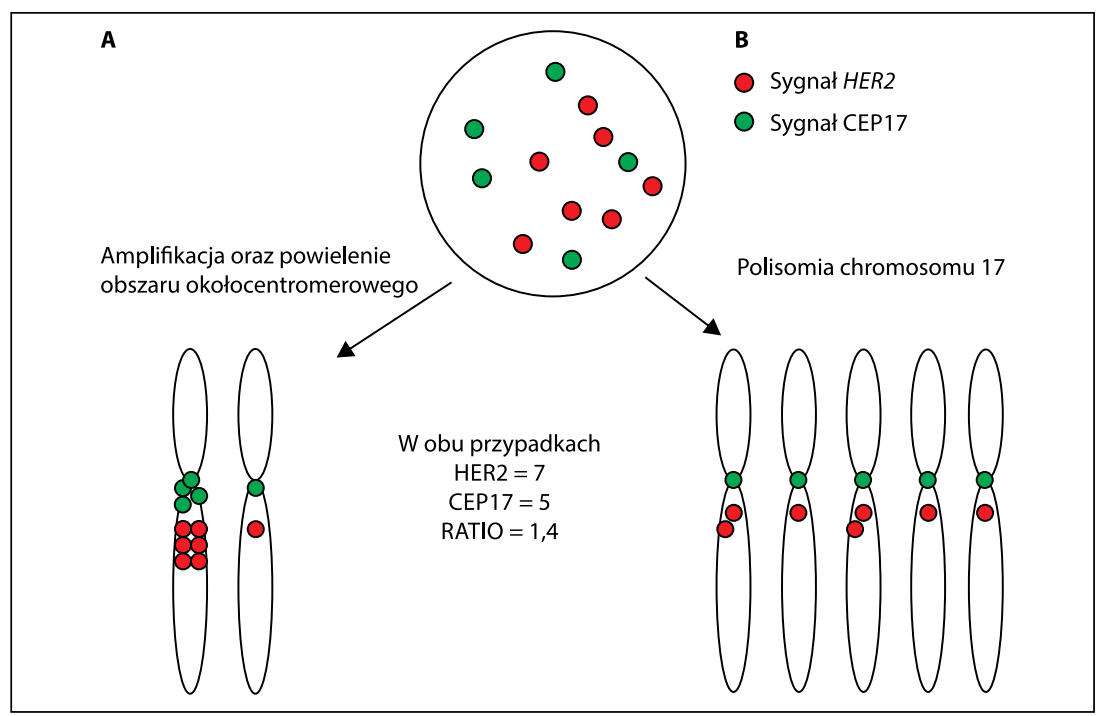

Rycina 2. Obraz widziany w mikroskopie fluorescencyjnym i schematyczne przedstawienie możliwości pochodzenia wzoru znakowania. A — amplifikacja obszaru okołocentromerowego i genu HER2; B — polisomia chromosomu 17

Tabela I. Porównanie wytycznych ASCO-CAP 2007 i ASCO-CAP 2013 dla oceny statusu genu HER2 metodą FISH z zastosowaniem sondy podwójnej, znakującej HER2 i CEP17

\begin{tabular}{lc}
\hline Wytyczne ASCO-CAP 2007 & Wytyczne ASCO-CAP 2013 \\
\hline RATIO* $>2,2^{\text {Wynik pozytywny (HER2-dodatni) }- \text { amplifikacja obecna }}$ \\
\hline & RATIO $\geq 2,0$ \\
& RATIO $<2,0$ oraz średnia liczba sygnałów HER2 na komórkę $\geq 6,0$ \\
\hline RATIO 1,8-2,2 & Wynik niejednoznaczny - status amplifikacji nieokreślony \\
\hline & RATIO $<2,0$ oraz średnia liczba sygnałów HER2 na komórkę $\leq 4,0$ oraz $<6,0$ \\
\hline RATIO $<1,8$ & Wynik negatywny (HER2-ujemny) - brak amplifikacji \\
\hline RATIO - stosunek liczby HER2:CEP17 & RATIO $<2,0$ oraz średnia liczba sygnałów HER2 na komórkę $<4,0$
\end{tabular}

*RATIO - stosunek liczby HER2:CEP17

wykonywanym na materiale jąder interfazowych, nieujawniającym morfologii chromosomu 17. Obecnie uważa się, że prawdziwa polisomia, czyli powielenie całego chromosomu 17, jest w raku piersi zjawiskiem bardzo rzadkim, częściej zaś występuje wybiórcze powielenie obszaru okołocentromerowego [21-23].

Obowiązujące obecnie wytyczne ASCO-CAP 2013 wprowadziły istotne zmiany w ocenie statusu genu HER2, szczególnie w przypadku stosowania sondy podwójnej. Uprzednio ocenę wykonywano, wyznaczając RATIO, natomiast obecnie należy dokonać równoległej oceny średniej ilości sygnałów pochodzących z sondy znakującej gen HER2 [14, 15]. W przypadku, gdy RATIO wynosi co najmniej 2,0, wynik badania jest pozytywny i wskazuje na obecność amplifikacji. Za pozytywne uznane są również przypadki z RATIO poniżej 2,0, w których średnia ilość sygnałów HER2 na komórkę wynosi co najmniej 6,0. Przypadki o negatywnym statusie genu HER2 wykazują RATIO mniejsze od 2,0 przy średniej liczbie sygnałów HER2 na komórkę poniżej 4,0.
Znacznemu rozszerzeniu uległa grupa wyników niejednoznacznych (dawniej granicznych). Są to przypadki, w których RATIO jest mniejsze niż 2,0, a średnia liczba sygnałów pochodzących od genu HER2 mieści się w przedziale od 4,0 do poniżej 6,0 (tab. I) [14, 15].

Kryteria oceny w przypadku zastosowania sondy pojedynczej uległy niewielkim korektom. Wynik pozytywny stwierdza się, gdy średnia liczba sygnałów HER2 na komórkę jest większa lub równa 6,0 (wg ASCO-CAP 2007 — jeśli przekracza 6,0). Wynik niejednoznaczny wyznacza obecnie średnia liczba sygnałów HER2 większa lub równa 4,0, a mniejsza niż 6,0 (wg ASCO-CAP 2007 > 4,0i < 6,0). Wartości dotyczące wyniku negatywnego pozostały bez zmian: średnia poniżej 4,0 kopii na komórkę [14, 15].

Celem niniejszej pracy była demonstracja wpływu zmiany wytycznych ASCO-CAP na ocenę statusu genu HER2 metodą FISH. Przeprowadzono analizę statusu genu HER2 u pacjentów diagnozowanych w naszej pracowni zgodnie z rekomendacjami ASCO-CAP 2007 i ASCO-CAP 2013. 
Tabela II. Rozkład wyników analizy statusu genu HER2 jednolitej grupy 763 tych samych pacjentów według dwóch różnych systemów wytycznych (ASCO-CAP 2007 i ASCO-CAP 2013)

\begin{tabular}{lcccccc}
\hline Status genu HER2 & Wynik & ASCO-CAP 2007 & & \multicolumn{2}{c}{ ASCO-CAP 2013 } & $\begin{array}{c}\text { Istotność } \\
\text { statystyczna }\end{array}$ \\
\cline { 3 - 5 } & $\begin{array}{c}\text { Odsetek } \\
\text { przypadków }\end{array}$ & $\begin{array}{c}\text { Liczba } \\
\text { przypadków }\end{array}$ & $\begin{array}{c}\text { Odsetek } \\
\text { przypadków }\end{array}$ & $\begin{array}{c}\text { Liczba } \\
\text { przypadków }\end{array}$ & $\mathbf{p = 0 , 0 0 0 5}$ \\
\hline Amplifikacja & pozytywny & $10,6 \%$ & $\mathrm{n}=81$ & $16,8 \%$ & $\mathrm{n}=128$ & $\mathbf{p}<\mathbf{0 , 0 0 0 1}$ \\
Brak amplifikacji & negatywny & $85,2 \%$ & $\mathrm{n}=650$ & $67,6 \%$ & $\mathrm{n}=516$ & $\mathrm{p}<\mathbf{0 , 0 0 0 1}$ \\
NDO* & $\begin{array}{l}\text { graniczny/ } \\
\text { /niejednoznaczny* }\end{array}$ & $4,2 \%$ & $\mathrm{n}=32$ & $15,6 \%$ & $\mathrm{n}=119$ & \\
Suma & & $100 \%$ & $\mathrm{n}=763$ & $100 \%$ & $\mathrm{n}=763$ & \\
\hline
\end{tabular}

*NDO - nie do oceny

**Wynik graniczny/niejednoznaczny — brak możliwości jednoznacznej oceny statusu genu HER2

Różnice istotne statystycznie zaznaczono pogrubioną czcionką

\section{Materiały i metody}

Analizę porównawczą przeprowadzono w oparciu o wyniki uzyskane $z$ rutynowej oceny statusu genu HER2 metodą FISH, na materiale tkankowym utrwalonym $w$ formalinie i zatopionym w parafinie. Badanie wykonywano w komórkach inwazyjnego raka piersi w materiale ocenionym uprzednio przez patologa dla potwierdzenia obecności i zasięgu utkania nowotworowego.

Pierwszą badaną grupę stanowiło 763 przypadków ocenianych w laboratorium w trakcie jednego roku. Z grupy poddanej analizie wyłączono przypadki niediagnostyczne, z niezadowalającą jakością znakowania lub zbyt skąpym utkaniem nowotworowym. W tej grupie u wszystkich pacjentów zastosowano równolegle dwa kryteria oceny: ASCO-CAP z roku 2007 i ASCO-CAP z roku 2013. Porównano wyniki uzyskane w obu trybach analizy.

Ponadto porównano wyniki analizy FISH uzyskane w dwóch różnych, niezależnych grupach pacjentów badanych rutynowo w naszym laboratorium w latach 2013 i 2014. Grupa 680 pacjentów z 2013 roku analizowana była według kryteriów ASCO-CAP 2007. Grupę 851 pacjentów z 2014 roku analizowano według kryteriów ASCO-CAP 2013. Do analizy porównawczej włączono zarówno wyniki diagnostyczne, jak i niediagnostyczne.

Procedurę FISH przeprowadzano przy użyciu aparatów VP2000 (ABBOTT) i ThermoBrite (ABBOTT). Do znakowania użyto podwójnej sondy PathVysion HER-2 DNA Probe Kit II z certyfikatem CE-IVD (Vysis, ABBOTT), zgodnie z zaleceniami producenta. Sonda znakująca gen HER2 była znakowana na czerwono, centromer 17 - na zielono. Pod uwagę brano jedynie preparaty, w których widoczne były obydwa kolory znakowania. Analizy znakowania dokonano przy użyciu mikroskopu fluorescencyjnego BX41 (Olympus). RATIO wyznaczano na podstawie zliczonych sygnałów z minimum 60 jąder komórkowych w reprezentatywnym obszarze preparatu.

Analiza statystyczna została przeprowadzona testem zgodności $\chi^{2}$.

\section{Wyniki}

Wyniki analizy porównawczej statusu genu HER2, ocenianego na podstawie zaleceń ASCO-CAP 2007 oraz ASCO-CAP 2013, w jednolitej grupie 763 pacjentów zestawiono w tabeli II.

Analiza przeprowadzona według wytycznych ASCO-CAP 2007 ujawniła wynik pozytywny, oznaczający amplifikację genu HER2, u 10,6\% ( $\mathrm{n}=81)$ przebadanych pacjentów. W przypadkach tych RATIO zawierało się w granicach od 2,21 do > 10. Wynik negatywny (brak amplifikacji HER2) stwierdzono w 85,2\% ( $n=650)$ przypadków, gdzie RATIO zawierało się w zakresie od 0,45 do 1,79 . Wynik pozostał niejednoznaczny, niepozwalający na jednoznaczne zdefiniowanie statusu powielenia $H E R 2$, w 4,2\% $(n=32)$ przypadków (RATIO od 1,81 do 2,19).

Powtórna analiza przeprowadzona w tej samej grupie pacjentów według wytycznych ASCO-CAP 2013 ujawniła wynik pozytywny u $16,8 \%(n=128)$ pacjentów (RATIO od $1,12$ do $>10)$. Wynik był negatywny w $67,6 \%(n=516)$ z RATIO w zakresie od 0,45 do 1,94 . Natomiast w $15,6 \%(n=119)$ uzyskano wynik niejednoznaczny (RATIO od 0,96 do 1,93).

Zmiana kwalifikacji wyniku oceny statusu genu HER2 dotyczyła 21,4\% przebadanych przypadków. Wszystkie wyniki pozytywne uzyskane według wytycznych ASCO-CAP 2007 u 81 pacjentów pozostały pozytywne po zastosowaniu wytycznych z 2013 roku. W grupie 650 wyników negatywnych według ASCO-CAP 2007 po zastosowaniu nowych wytycznych $79,1 \%(n=514)$ przypadków ponownie zostało zakwalifikowanych jako negatywne, 3,4\% $(n=22)$ reklasyfikowano na wynik pozytywny, natomiast $17,5 \%(n=114)$ na wynik niejednoznaczny (ryc. 3A). W grupie 32 wyników granicznych według ASCO-CAP 2007 po zastosowaniu nowych wytycznych $15,6 \%(n=5)$ nie zmieniło swojego statusu, $78,1 \%(n=25)$ zostało zaklasyfikowanych jako pozytywne, natomiast 6,3\% $(n=2)$ jako negatywne (ryc. 3B).

Porównanie wyników uzyskanych w dwóch różnych grupach pacjentów ocenianych w kolejnych latach zgodnie 


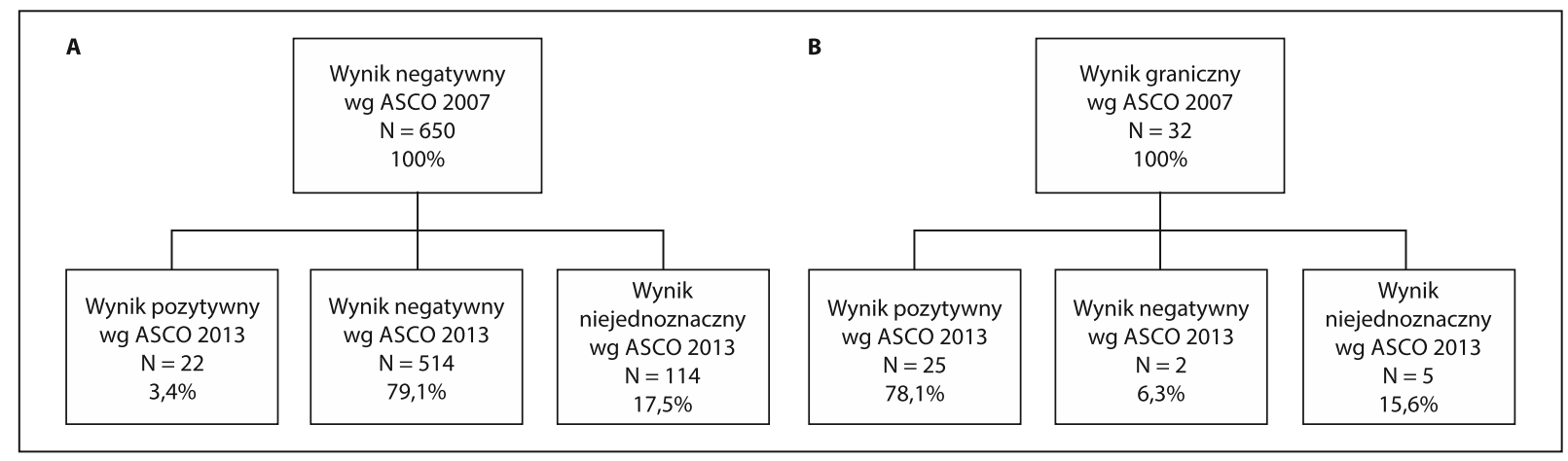

Rycina 3. Wpływ zmiany zasad klasyfikacji ASCO-CAP na kwalifikację wyników tej samej grupy 763 pacjentów. A — zmiany w grupie wyników negatywnych wg 2007; B — zmiany w grupie wyników granicznych wg 2007

Tabela III. Rozkład wyników dwóch niezależnych grup pacjentów, analizowanych według dwóch różnych systemów wytycznych

\begin{tabular}{|c|c|c|c|c|c|c|}
\hline \multirow[t]{2}{*}{ Status genu HER2 } & \multirow[t]{2}{*}{ Wynik } & \multicolumn{2}{|c|}{$\begin{array}{l}\text { ASCO-CAP } 2007 \\
\text { Grupa }(n=680)\end{array}$} & \multicolumn{2}{|c|}{$\begin{array}{l}\text { ASCO-CAP } 2013 \\
\text { Grupa }(n=851)\end{array}$} & \multirow[t]{2}{*}{$\begin{array}{c}\text { Istotność } \\
\text { statystyczna }\end{array}$} \\
\hline & & $\begin{array}{c}\text { Odsetek } \\
\text { przypadków }\end{array}$ & $\begin{array}{c}\text { Liczba } \\
\text { przypadków }\end{array}$ & $\begin{array}{c}\text { Odsetek } \\
\text { przypadków }\end{array}$ & $\begin{array}{c}\text { Liczba } \\
\text { przypadków }\end{array}$ & \\
\hline Amplifikacja & pozytywny & $15,6 \%$ & $n=106$ & $15,4 \%$ & $n=131$ & $p=0,92$ \\
\hline Brak amplifikacji & negatywny & $76,2 \%$ & $n=518$ & $61,8 \%$ & $n=526$ & $p<0,0001$ \\
\hline NDO* & graniczny/niejednoznaczny** & $0,4 \%$ & $\mathrm{n}=3$ & $13,6 \%$ & $\mathrm{n}=116$ & $p<0,0001$ \\
\hline NDO & niediagnostyczne $e^{* *}$ & $7,8 \%$ & $n=53$ & $9,2 \%$ & $\mathrm{n}=78$ & $p=0,34$ \\
\hline
\end{tabular}

*NDO - nie do oceny

**Wynik graniczny/niejednoznaczny — brak możliwości jednoznacznej oceny statusu genu HER2

Różnice istotne statystycznie zaznaczono pogrubioną czcionką

z zaleceniami ASCO-CAP 2007 i ASCO-CAP 2013 przedstawiono w tabeli III. Wyniki badania FISH u 680 pacjentów diagnozowanych w roku 2013 oceniano według wytycznych ASCO-CAP 2007. Wyniki badania FISH 815 pacjentów diagnozowanych w roku 2014 oceniano według wytycznych ASCO-CAP 2013.

Porównanie to ujawniło brak znaczących zmian w odsetku przypadków HER2-pozytywnych. W grupie pacjentów ocenianej wg zasad 2007 uzyskano 15,6\% wyników pozytywnych, w grupie ocenianej wg zasad 2013 uzyskano 15,4\% wyników pozytywnych, a stwierdzona różnica nie jest istotna statystycznie. Jednocześnie w grupie analizowanej według wytycznych 2013 stwierdzono spadek odsetka wyników HER2-negatywnych w porównaniu z grupą analizowaną według wytycznych 2007 (61,8\% vs 76,2\%). Znacznemu rozszerzeniu uległa grupa z wątpliwym statusem genu HER2: z 0,4\% (wg wytyczne 2007) do 13,6\% (wg wytyczne 2013). Grupa przypadków niediagnostycznych, w których jakość materiału lub zbyt skąpe utkanie nowotworowe uniemożliwiały wykonanie badania, pozostała na podobnym poziomie (7,8 vs 9,2\%).

\section{Dyskusja}

Interpretacja wyniku badania FISH, przeprowadzonego dla oceny statusu genu HER2 w celu wyselekcjonowania pacjentów z amplifikacją tego genu, powinna odbywać się zgodnie z aktualnie obowiązującymi zaleceniami ekspertów ASCO-CAP $2013[14,15]$.

Rekomendacja z 2007 roku definiowała przypadki z amplifikacją, przypadki bez amplifikacji i przypadki graniczne, o niemożliwym do zdefiniowania statusie genu HER2 [20]. Dla uściślenia wyniku stosowano zliczanie sygnałów w dodatkowych jądrach, a gdy wynik pozostawał niejednoznaczny, zalecano powtórzenie badania FISH lub IHC. Mankamentem tej klasyfikacji była zależność wyniku od rodzaju użytej sondy. Zdarzały się sytuacje, gdy u tego samego pacjenta można było uzyskać wynik pozytywny w przypadku użycia sondy znakującej tylko gen HER2 lub wynik negatywny — przy użyciu sondy podwójnej, znakującej dodatkowo obszar CEP17. Sytuacja taka pojawiała się, gdy średnia liczba sygnałów HER2 na komórkę była większa niż 6 (wynik pozytywny), natomiast RATIO było mniejsze od 1,8 (wyniknegatywny). Zaniżenie wskaźnika RATIO wynikało tu z podwyższonej liczby kopii CEP17.

Obecnie obowiązujące wytyczne ASCO-CAP 2013 zobowiązują do równoległej oceny średniej ilości sygnałów pochodzących z sondy znakującej gen HER2 z analizą RATIO $[14,15]$. Jest to zatem połączenie dwóch metod analizy dla uzyskania jak najbardziej wiarygodnego wyniku. Utrzymano podział na przypadki pozytywne, z jednoznaczną amplifika- 
cją, oraz negatywne, z jednoznacznym brakiem amplifikacji. Grupa przypadków o nieustalonym statusie genu HER2 nazwana została grupą niejednoznaczną. Odpowiada ona po części dawnej grupie przypadków granicznych oraz negatywnych. Zmiana zasad kwalifikacji spowodowała zmianę w proporcji liczebności grup pacjentów z wykazaną amplifikacją, bez amplifikacji oraz przypadków niezdefiniowanych wobec statusu genu HER2.

W przeprowadzonych przez nas badaniach analiza wyników uzyskanych na tej samej grupie pacjentów przy użyciu dwóch systemów klasyfikacji potwierdziła tę tendencję. Wszystkie wyniki pierwotnie pozytywne (wg ASCO-CAP 2007) pozostały takimi po zastosowaniu wytycznych ASCO-CAP 2013.Z grupy wyników pierwotnie negatywnych ponad 3\% zostało przeniesionych do grupy wyników pozytywnych, zaś prawie 18\% - do grupy niejednoznacznej. Pierwotne wyniki graniczne zostały w większości uznane za pozytywne (78\% grupy), w niewielkiej części — za negatywne (6\%), a niecałe $16 \%$ pozostało niezdefiniowane pod względem statusu genu HER2, zasilając ostatecznie grupę wyników niejednoznacznych. Sumarycznie, po reklasyfikacji grupa przypadków HER2-pozytywnych wzrosła z 81 do 128 przypadków, co stanowi ponad 6\% grupy badanej. Największy wzrost, o ponad $11 \%$, odnotowano w grupie przypadków niejednoznacznych: z 4,2\% do 15,6\%. Obok przypadków z wyjściowej grupy granicznej do przypadków niejednoznacznych zaliczono nowe, które pochodziły z grupy wyjściowo ocenionej jako negatywne. Po reklasyfikacji odnotowano spadek odsetka przypadków z wynikiem negatywnym z 85,2\% do 67,6\%; zmiana ta stanowiła ponad $17 \%$. Wszystkie wykazane różnice były istotne statystycznie. Uzyskane przez nas rezultaty potwierdziły przewidywaną teoretycznie zmianę proporcji liczbowych poszczególnych grup pacjentów.

Podobne wyniki otrzymano w Mayo Clinic. Po przeprowadzonej analizie 321 przypadków stwierdzono zmianę statusu genu HER2 u 15\% badanych (w naszym laboratorium ponad $21 \%$ ). Grupa $z$ wynikiem pozytywnym wzrosła z $14 \%$ do $25 \%$, natomiast negatywna zmalała z $82 \%$ do 70\%, odpowiednio wytyczne 2007 vs 2013. Inaczej niż w naszych badaniach, tylko niewielkiemu powiększeniu uległa grupa przypadków niejednoznacznych z 3,5\% do 4\% [24]. W badaniach w Kanadzie stwierdzono reklasyfikację wyników w ponad 9\% z 904 przebadanych przypadków [25]. W grupie przypadków pierwotnie zaklasyfikowanych jako negatywne 7,3\% zmieniło kwalifikację na wynik niejednoznaczny, a 0,7\% na wynik pozytywny. W grupie przypadków pierwotnie niejednoznacznych $1 \%$ otrzymało wynik pozytywny, zaś $0,4 \%$ wynik negatywny. Wszystkie wyniki pozytywne pozostały pozytywne. W grupie pozytywnej odnotowano niewielki wzrost, o 1,7\%, natomiast w grupie przypadków niejednoznacznych odnotowano wzrost z 2,3\% do 7,3\% przypadków [25].
Porównanie naszych wyników rutynowych badań FISH, przeprowadzanych w dwóch kolejnych latach, w niezależnych grupach pacjentów o podobnej liczebności, wykazało istotny statystycznie spadek liczebności grupy HER2-ujemnej z 76,2\% do 61,8\% . Wzrost odsetka przypadków niejednoznacznych przekroczył 13\%. Liczebność grupy o nieustalonym statusie HER2 zmieniła się najbardziej. W wyniku opisanego porównania stwierdzono ponadto utrzymanie poziomu przypadków pozytywnych (HER2-dodatnich) na poziomie 15\% (różnica nieistotna statystycznie). Taki rezultat może wynikać z odmiennego doboru grupy kierowanej na badanie FISH w kolejnych latach. Po zmianie wytycznych ASCO-CAP modyfikacji uległy również zalecenia dotyczące oceny badania immunohistochemicznego, w tym definicje IHC 3+, 2+, 1+ i 0. W szczególności zostało zmienione kryterium oznaczenia $3+$ (z 30\% do 10\% - silne wybarwienie błony), co mogło wpłynąć na zmniejszenie odsetka przypadków ewidentnie pozytywnych, kierowanych wcześniej do badania FISH. Dodatkowo rozszerzono grupę 2+, wymagającą badania FISH, o przypadki, które według poprzednich rekomendacji kwalifikowane były jako HER2-negatywne [26, 27].

Efektem nowych wytycznych ASCO-CAP 2013 miało być umożliwienie zastosowania terapii celowanej przeciwko HER2 u jak największej grupy pacjentów potencjalnie wrażliwych na takie leczenie oraz zmniejszenie ryzyka otrzymania wyniku fałszywie negatywnego [14, 25]. Skutkiem zmian $w$ rekomendacjach było rozszerzenie grupy przypadków HER2-dodatnich (z amplifikacją), a zawężenie grupy przypadków HER2-ujemnych (bez amplifikacji). Rozszerzenie grupy wyników niejednoznacznych połączono ze wskazaniem możliwości zastosowania terapii anty-HER2 także u niektórych pacjentów z tej grupy. Zakładano przy tym, iż w przypadkach, bez jednoznacznie stwierdzonej lub wykluczonej amplifikacji genu HER2, ostateczna decyzja o odpowiednim protokole leczenia, zostanie podjęta w wyniku konsultacji lekarza onkologa i patologa na podstawie analizy całościowych danych klinicznych [14, 25].

Na podstawie wyników własnych możemy stwierdzić, że zastosowanie obowiązujących wytycznych ASCO-CAP 2013 zwiększyło grupę przypadków niejednoznacznych, o niezdefiniowanym statusie genu HER2. Pacjenci ci stanowią obecnie szczególny problem diagnostyczny. W warunkach polskich, gdzie decyzje o podjęciu leczenia są podejmowane administracyjnie (zalecenia NFZ), wzrastająca grupa przypadków niejednoznacznych, niekwalifikowanych do terapii celowanej, rodzi liczne wątpliwości i dylematy diagnostyczne i kliniczne.

Niejednoznaczny wynik FISH może wynikać z trzech zasadniczych przyczyn. Pierwszą może być gorsza jakość badanego materiału biologicznego, drugą zaś jego heterogenność, oznaczająca niejednorodność genetyczną próbki. Trzecią możliwą przyczyną niejednoznaczności wyniku jest 
brak możliwości rozróżnienia ko-amplifikacji HER2/CEP17 od polisomii chromosmu $17 \mathrm{w}$ badaniu rutynowym.

Powtórzenie rutynowego badania FISH na innym bloczku czy analiza większej populacji komórek mogą być skuteczne w dwóch pierwszych przypadkach, jednak nie rozstrzygają wątpliwości w trzeciej grupie przypadków niejednoznacznych, z nietypowym obrazem znakowania [18, 25].

Heterogenność materiału oznacza tu, że w guzie występują różne populacje komórek nowotworowych, w tym klon obciążony amplifikacją HER2. Zjawisko takie może dotyczyć nawet 40\% przypadków [18]. Komórki z amplifikacją HER2 mogą być umiejscowione w wyodrębnionych obszarach guza bądź być przemieszane z komórkami bez amplifikacji [15]. Dowiedziono, że praktyczny wpływ na przebieg choroby ma obecność klonów wyodrębnionych, o liczebności nie mniejszej niż 10\% badanej populacji, a obszary te powinny być oceniane oddzielnie [15, 18]. Ocena heterogenności próbki powinna być więc nieodłączną częścią rutynowej analizy FISH, zaś w przypadkach niejednoznacznych powinna być przeprowadzona powtórnie.

Nietypowe znakowanie, czyli równoczesne zwielokrotnienie liczby sygnałów genu HER2 i centromeru chromosomu 17, notowane jest nawet w $46 \%$ przypadków raka piersi [18]. Analiza FISH w jądrach interfazowych pozwala na określenie liczby kopii znakowanego obszaru, ale nie ich wzajemne położenie. Tak więc nadliczbowe kopie HER2 mogą być zgromadzone na jednym, zmienionym chromosomie 17 (amplifikacja) lub występować na wielu kopiach prawidłowego chromosomu 17 (polisomia/poliploidia). Zalecane użycie innej sondy znakującej centromer 17 lub sond znakujących inne geny leżące na tym chromosomie, np. TP53, SMS, RARA, ma ujawnić zaburzenia morfologii lub liczby kopii chromosomu 17 [6, 14, 15, 18, 23]. Celem rozszerzonego badania FISH jest więc wykazanie statusu genu HER2 wobec morfologii chromosomu 17 w przypadkach, gdzie stosunek HER2/CEP17 wynosi poniżej 2,0, a liczba kopii genu HER2 nie osiąga 6,0. Jeśli doszło do ko-amplifikacji (równoczesnego powielenia) CEP17 i HER2 w jednej z dwóch kopii chromosomu 17, skutek kliniczny jest równoznaczny z amplifikacją (wynik HER2+). Jeśli zaś przyczyną powielenia sygnałów jest polisomia (obecność kilku kopii) chromosomu 17 bądź poliploidia komórek (powielenie kopii wszystkich chromosomów), wynik będzie ujemny lub pozostanie niejednoznaczny. Dotychczasowe badania z zastosowaniem takich metod jak MLPA, aCGH czy FISH z użyciem innych sond znakujących chromosom 17 sugerują, iż podwyższona wartość CEP17 rzadko jest skutkiem polisomii 17 [18, 21, 28], co jest argumentem na rzecz wykonywania pogłębionych badań w przypadkach niejednoznacznych. Takie postępowanie może wskazać grupę przypadków z amplifikacją, nieujawnioną w badaniu rutynowym.

Niestety, pogłębiona analiza FISH istotnie podnosi koszty rutynowej procedury oznaczania, co przy obecnym stanie finansowania badań genetycznych może stanowić istotny problem dla szpitali. Dysponując szerokim materiałem diagnostycznym, podjęliśmy próbę ustalenia optymalnej procedury pogłębionego badania FISH w przypadkach niejednoznacznych. Wyniki badania zostaną przedstawione w osobnej publikacji.

\section{Wnioski}

Wykazano, że zmiana wytycznych ASCO-CAP wpłynęła istotnie na rezultat oznaczenia statusu genu HER2 metodą FISH. Efektem obecnej zmiany jest rozszerzenie grupy wyników HER2-dodatnich przy jednoczesnym zmniejszeniu grupy HER2 - ujemnej. Znaczny wzrost liczebny grupy wyników niejednoznacznych implikuje potrzebę wdrożenia procedury ich weryfikacji.

\section{Konflikt interesów: nie zgłoszono}

\section{Mgr Urszula Piekarska}

Pracownia Genetyki Nowotworów

Zakład Patologii i Diagnostyki Laboratoryjnej

Centrum Onkologii — Instytut

im. Marii Skłodowskiej-Curie w Warszawie

ul. Roentgena 5, 02-781 Warszawa

e-mail:unajmola@coi.waw.pl

Otrzymano: 30 listopada $2015 r$

Przyjęto do druku: 16 lutego $2016 r$.

\section{Piśmiennictwo}

1. Jassem J, Krzakowski M, Bobek-Billewicz i wsp. Rak piersi. W: Jassem J, Krzakowski M (red.) Zalecenia postępowania diagnostyczno-terapeutycznego w nowotworach złośliwych — 2013. Gdańsk: Via Medica, 2013; 212-263.

2. Wojciechowska U, Didkowska J. Zachorowania i zgony na nowotwory złośliwe w Polsce. Krajowy Rejestr Nowotworów, Centrum Onkologii Instytut im. Marii Skłodowskiej-Curie (http://onkologia.org.pl/raporty/.

3. Salamon DJ, Godolphin W, Jones LA i wsp. Studies of the HER-2/neu proto-oncogene in human breast and ovarian cancer. Science 1989; 244: 707-712.

4. Coussens L, Yang-Feng TL, Liao YC i wsp. Tyrosine kinase receptor with extensive homology to EGF receptor shares chromosomal location with neu oncogene. Science 1985; 230: 1132-1139.

5. Hynes NE, Stern DF. The biology of erbB-2/neu/HER-2 and its role in cancer. Biochim Biophys Acta 1994; 1198: 165-184.

6. Tse $\mathrm{CH}$, Hwang HC, Goldstein LC i wsp. Determining true HER2 gene status in breast cancers with polisomy by using alternative chromosome 17 reference genes: implicationes for anti-HER2 targeted therapy. J Clin Oncol 2011; 29: 4168-4174.

7. Roskoski R Jr. The ErbB/HER receptor protein-tyrosine kinases and cancer. Biochem Biophys Res Communic 2004; 319: 1-11.

8. Di Fiore PP, Pierce JH, Kraus MH i wsp. erbB- 2 is a potent oncogene when overexpressed in NIH/3t3 cells. Science 1987; 237: 178-182.

9. Dowsett M, Procter M, McCaskill-Stevens W i wsp. Disease-free survival according to degree of HER2 amplification for patients treated with adjuvant chemotherapy with or without 1 year of trastuzumab: the HERA Trial. J Clin Oncol 2009; 27: 2962-2969.

10. Ross JS, Slodkowska EA, Symmans WF i wsp. The HER2-receptor and breast cancer: ten years of targeted anti-HER-2 therapy and personalized medicine. The Oncologist 2009; 14: 320-368.

11. Olszewski WP. Status HER2 w raku piersi — informacje praktyczne dla lekarzy. Nowa Medycyna 2005; 12: 4-10.

12. Krasińska L, Jassem J. Kliniczne znaczenie zaburzeń HER2 w raku piersi z uwzględnieniem metod ich oznaczania. Nowotwory J Oncol 2003; 53: 68-71. 
13. European Cytogeneticists Assiciation (E.C.A.) Permanent Working Group for Cancer cytogenetics solid tumor studies. Interphase FISH on solid tumors: recommendations for use on histological sections in daily practice. Newsletter 2011; 27: 5-11.

14. Wolff AC, Hammond ME, Hicks DG i wsp. Recommendations for human epidermal growth factor receptor 2 testing in breast cancer: American Society of Clinical Oncology/College of American Pathologists clinical practice guideline update. J Clin Oncol 2013; 31: 3997-4013.

15. Wolff AC, Hammond ME, David G i wsp. Recommendations for human epidermal growth factor receptor 2 testing in breast cancer: American Society of Clinical Oncology/College of American Pathologists Clinical Practice Guideline Update. Arch Pathol Lab Med 2014; 138: 241-256.

16. Śnietura M, Lange D. Aktualne rekomendacje ASCO/CAP 2013 dotyczące badań statusu receptora HER2 $\mathrm{w}$ raku piersi. Polish Journal of Pathology 2014; 65 (Suplement 2): S32-41.

17. Olszewski WT, Krzakowski M i wsp. Rekomendacje polskiej grupy badawczej ds. HER2. Nowotwory J Oncol 2004; 54: 500-505.

18. Hanna WM, Rüschoff J, Bilous M i wsp. HER2 in situ hybridization in breast cancer: clinical implications of polysomy 17 and genetic heterogeneity. Mod Pathol 2014; 27: 4-18.

19. Perez EA, Cortes J, Gonzalez-Angulo AM i wsp. HER2 testing: current status and future directions. Cancer Treat Rev 2014; 40: 276-284.

20. Wolff AC, Hammond ME, Schwarz JN i wsp. American Society of Clinical Oncology/College of American Pathologists guideline recommendations for human epiderma growth factor receptor 2 testing in breast cancer. Arch Pathol Lab Med 2007; 131: 18-43.

21. Gunn S, Yeh IT, Lytvak I i wsp. Clinical array-based karyotyping of breast cancer with equivocal HER2 status resolves gene copy number and reveals chromosome 17 complexity. BMC Cancer 2010; 10: 396.
22. Vranic S, Teruya B, Repertinger S i wsp. Assessment of HER2 gene status in breast carcinoma with polysomy of chromosome 17. Cancer 2011; 117: 48-53.

23. Egervari K, Kosa C, Szollosi Z, Impact of chromosome 17 centromere region assessment on HER2 status reported in breast cancer. Pathol Res Pract 2011; 207: 468-471.

24. Shah MV, Wiktor AE, Meyer RG i wsp. Changing pattern for HER2 positivity due to updated ASCO/CAP guidelines for HER2 testing and its impact. Journal of Clinical Oncology. ASCO Annual Meeting Abstracts 2014; $32: 523$.

25. Bethune GC, Veldhuijzen van Zaten D, Maclntosh RF i wsp. Impact of the 2013 American Society of Clinical Oncology/College of American Pathologist guideline recommendationes for human epidermal growth factor receptor 2 (HER2) testing of invasive breast carcinoma: a focus on tumors assessed as 'equivocal' for HER2 gene amplification by fluorescence in-situ hybridization. Histopathology 2015; 67: 880-887.

26. Rakha EA, Starczynski J, Lee AH i wsp. The updated ASCO/CAP guideline recommendations for HER2 testing in the management of invasive breast cancer: a critical review of their implications for routine practice. Histopathology 2014; 64: 609-615.

27. Garbar C, Savoye AM, Mascaux C i wsp. The human epidermal growth factor receptor 2 screening test for breast cancer suggested by the new updated recommendation of American Society of Clinical Oncology/College of American Pathologists will involve a rise of the in-situ hybridization test for the European laboratories of pathology. ISRN Oncology 2014; 2014: ID 793695.

28. Moelans CB, de Weger RA, van Diest PJ, Absence of chromosome 17 polysomy in breast cancer: analysis by CEP17 chromogenic in situ hybridization and multiplex ligation-dependent probe amplification. Breast Cancer Res Treat 2010; 120: 1-7. 